\title{
George Pal, de vergeten Hongaarse Oscarwinnaar
}

\begin{abstract}
The name of the Hungarian animation film maker and producer George Pal (1908-1980) is almost unknown both in his home country Hungary and in the Netherlands, even though he played a key role in the formation of the Dutch animation film industry and was later granted with eight Oscars after he had emigrated to the USA. Once personally for the invention of a new animation film making technique, the so-called Puppetoon system. In this article I would like to summarize and fill his biography with until now unknown facts. Besides that, I would like to introduce his development, the puppetoonsystem and demonstrate why we should see Pal as the founder of the Dutch industrial animation production.

Keywords: George Pal, animation film, film history, Dutch film industry, puppetoons, Geesink, Dollywood, Machilsto
\end{abstract}

\section{Introductie}

George Pal was een Hongaarse filmregisseur, producer en animator. Hij begon zijn carrière in Hongarije bij de Hunnia filmstudio en later werkte hij in Duitsland, Tsjechoslowakije, Frankrijk en Nederland voordat hij naar de VS vluchtte.

Hij had grote invloed op het begin van de Nederlandse animatiefilm, maar het hoogtepunt van zijn carrière bereikte hij in Hollywood. Pal won 
zelf een Oscar 'for the development of novel methods and techniques in the production of short subjects known as Puppetoons' in 1943, ' maar hij was ook bij andere Oscars en nominaties betrokken. Daarnaast was zijn werk onderdeel van de ontwikkeling van sciencefiction en fantasy als filmgenres.

Toch is zijn naam in zijn geboorteland bijna geheel onbekend. Er zijn over zijn pionierswerk nog geen boeken verschenen, alleen een paar korte besprekingen in bijvoorbeeld lexica en in het boek És mégis mozog... (En toch beweegt zij...) van Eszter Dizseri. ${ }^{1}$ Hier wil ik graag een overzicht geven van zijn leven en werk.

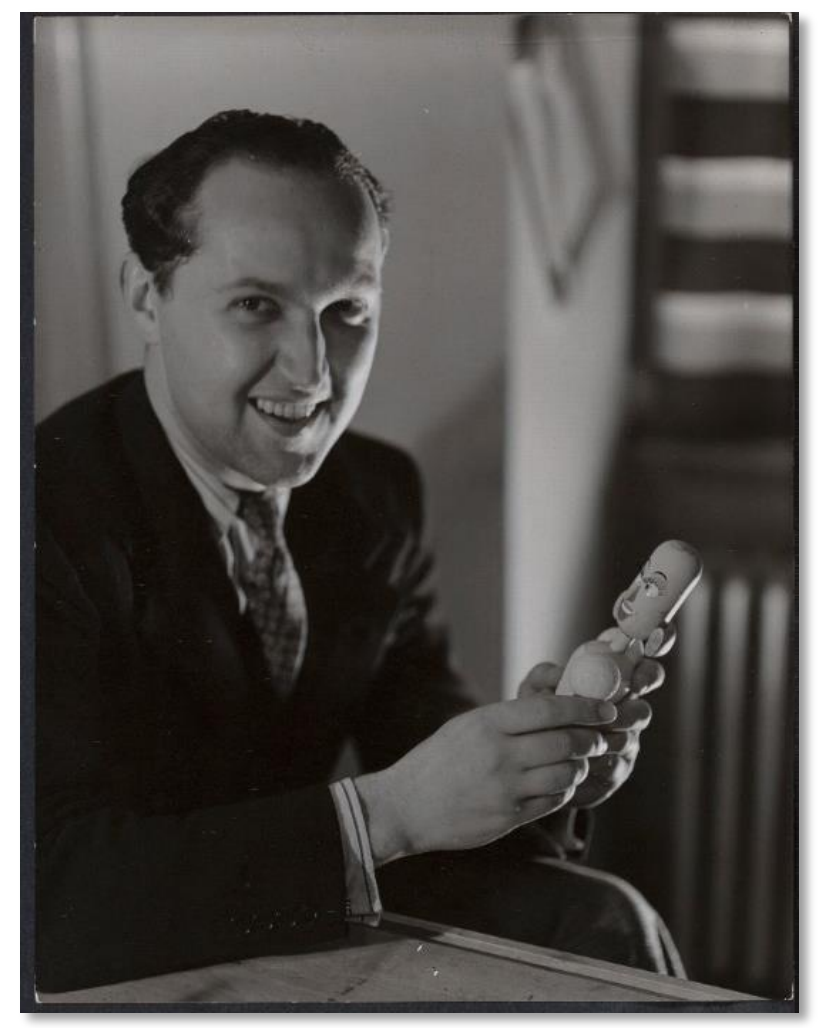

Illustratie 1: The Philips broadcast 1938 (Bron:collectie Stichting EYE Film Instituut Nederland)

'voor de ontwikkeling van nieuwe methoden en technieken in de productie van korte films, de zogenaamde Puppetoons' Eagan, America's film legacy, 347. 


\section{Oostenrijk-Hongarije}

Gyula György Marczincsák ${ }^{2}$, of zoals hij later bekend werd, George Pal, werd op 1 februari 1908 geboren in Oostenrijk-Hongarije, in de Hongaarse stad Cegléd, ${ }^{3}$ in een rooms-katholieke familie. ${ }^{4}$ Zijn ouders waren volgens de meeste bronnen artiesten die voor een rondreizend theater werkten. ${ }^{5}$ In het geboorteregister stond bij het beroep van Pals vader echter dat hij ober was. Over het beroep van zijn moeder weten we niets precies. De vader was 19 en de moeder was 23 jaar oud toen Pal geboren werd, ${ }^{6}$ en ze trouwden voor de kerk pas op 27 mei 1908, drie maanden na de geboorte van hun zoon. ${ }^{7}$

Het huwelijk van zijn ouders duurde niet lang. Na de scheiding verdween zijn vader en zijn moeder wilde haar zoontje ook niet opvoeden, alle twee ouders verlieten Pal dus. Daarom werd hij door zijn grootouders opgevoed, ${ }^{8}$ die waarschijnlijk bij het Nationaal Theater werkten. ${ }^{9}$ De naam van zijn voogd was József Szabó, die tijdens de studies van Pal al een gepensioneerde acteur was. Ze woonden in Boedapest, in Dembinszkystraat nummer $41 .^{10}$

Pal was zelf niet geïnteresseerd in het toneelspel, maar hij was wel artistiek ingesteld, ${ }^{11}$ dus hij studeerde vanaf 1924 voor meubeldesigner aan de kunstnijverheidsschool. ${ }^{12}$ Omdat zijn familie arm was, moest Pal elke mogelijkheid aangrijpen om geld te kunnen verdienen voor zijn studie. ${ }^{13}$ Hij verwierf bijvoorbeeld een witte doktersjas om met studenten medicijnen mee te kunnen gaan naar hun anatomieles. De studenten medicijnen moesten in die tijd weten hoe je spieren en botten kon tekenen ${ }^{14}$ omdat er nog geen anatomieatlas bestond. Pal kon heel goed tekenen, dus hij verkocht zijn tekeningen aan hen. Daarmee kon hij niet alleen geld verdienen, maar ook zijn tekenvaardigheid ontwikkelen. ${ }^{15}$ De professor vermoedde waarschijnlijk wat er aan de hand was omdat er te veel studenten heel erg op elkaar lijkende tekeningen inleverden. Maar hij zei niets. ${ }^{16}$ Een ander voorbeeld was dat hij fresco's schilderde in kerken. ${ }^{17}$

Pal moest als deel van zijn studie ervaring als timmerman of metselaar opdoen. Hij koos ervoor om als timmerman aan de slag te gaan, en dat bleek een goede keuze te zijn. Hij vond dit vak zo leuk dat hij, in plaats van één jaar, twee jaar als timmerman werkte en ook een timmermansdiploma behaalde. ${ }^{18} \mathrm{Hij}$ zei over die jaren: 'I think working with wood helped me an awful lot with the Puppetoons later on. I think without that experience I would probably never have invented the Puppetoon systeem. ${ }^{, 19}$ 
Nadat hij in 1928 afgestudeerd was, kon hij geen geschikte baan vinden vanwege de economische crisis. Duizenden werden werkloos in die tijd, ${ }^{20}$ maar hij werd uiteindelijk vanwege zijn handvaardigheid en anatomische kennis in dienst genomen bij de Hunnia filmstudio. ${ }^{21}$ Hij maakte daar illustraties om de ondertitelingen van de stomme films aantrekkelijker te maken en schilderde affiches voor bioscopen. ${ }^{22}$ Hij werkte samen met János Halász ${ }^{23}$ en Imre Hajdú ${ }^{24}$ die later ook belangrijke animatiefilmmakers werden.

Tijdens zijn jaren bij Hunnia raakte hij geïnteresseerd in tekenfilms. Hij wilde weten hoe ze geproduceerd werden, maar hij kon er geen boeken over vinden. Hij moest het dus zelf ontdekken ${ }^{25}$ en begon te tekenen naar het voorbeeld van de tekenfilmfiguren Felix the $\mathrm{Cat}^{26}$ en Oswald the Rabbit. ${ }^{27}$ Gelukkig ontmoette hij George Feld, een Hongaar die in Hollywood had gewerkt als filmmonteur. Feld wist hoe tekenfilms werden gemaakt en hij vertelde het aan Pal. Daarna moest hij nog zijn eigen middelen ontwikkelen ${ }^{28}$ om films te kunnen maken. In deze periode experimenteerde hij voor het eerst ook met object-animatie: hij probeerde een champagnefles te laten dansen. ${ }^{29}$

\section{Duitsland}

In 1930 verliet hij Hongarije omdat zijn latere vrouw, Zsóka Grandjean, niet in Hongarije wilde wonen want "ze maakte daar al te veel dingen mee". ${ }^{30}$ Wat ze daar precies mee bedoelde is niet duidelijk. Pal begon daarom te werken in Duitsland, in Berlijn. In het begin werkte hij voor een advertentiebureau, maar na korte tijd kreeg hij een baan bij UFA in Neu-Babelsberg bij de tekenfilmafdeling waarvan hij heel snel het hoofd werd. ${ }^{31}$

De filmstudio UFA (Universum Film AG) was in 1917 opgericht. De waarde van de studio werd toen door de Deutsche Bank op 25 miljoen mark geschat. In de jaren 20 , het gouden tijdperk van de studio, werd UFA één van de leidende filmstudio's ter wereld, een 'echte concurrent van Hollywood op de wereldmarkt'. ${ }^{32}$ De firma ging in 1945 , na de val van de nazi's, ten onder. ${ }^{33}$

Werkzaam bij deze studio bedacht Pal het figuur van een beer, Haba$k u k$, die een grote rivaal van Mickey Mouse $e^{34}$ werd in Europa. Naast Habakuk vervaardigden Pal en zijn collega's daar nog verhaaltjes over de tekenfilmfiguur Kollega. ${ }^{35}$ Pal moest als het hoofd van de afdeling alleen 
het scenario van de afleveringen schrijven en dan de belangrijkste posities tekenen. Daarna moesten zijn medewerkers de rest van de filmpjes tekenen, wat een echt monnikenwerk was aangezien er voor één aflevering 10.400 afbeeldingen moesten worden gemaakt. ${ }^{36}$

In 1932 besloot hij een eigen studio te openen. Vanwege zijn ervaring kreeg hij veel opdrachten, bijvoorbeeld van de sigarettenproducent Haus Neuerburg. ${ }^{37}$ Hij moest een reclamefilmpje maken over sigaretten, maar hij vond het snel vervelend om duizenden sigaretten te tekenen. Daardoor kreeg hij het idee om in plaats van tekeningen echte sigaretten te gebruiken. Het filmpje Midnight - waarschijnlijk zijn eerste poppenfilm werd zo'n groot succes dat het bedrijf nog andere films bestelde, waarin de sigaretten ook moesten spreken. ${ }^{38}$ Pal vertelde het volgende daarover: '[...] So we put little mouths on them - no face yet, just mouths. And then we put faces on them, and put hats on them, and put arms and legs on them. I built wire legs with buttons for feet and made a series of legs that way. And that was the birth of the Puppetoons. ${ }^{39}$

In 1933 kwam Hitler aan de macht. Pal werd door de Gestapo in de gaten gehouden vanwege zijn Hongaarse afkomst, dus besloot hij ook Duitsland te verlaten. ${ }^{40}$

\section{Tsjechoslowakije en Frankrijk}

Vanuit Duitsland verhuisde het echtpaar eerst naar Tsjechoslowakije. ${ }^{41}$ Daarbij was Dezső Grósz, die als Desider Gross zijn continentale reclamefilm-netwerk uit Praag regeerde, hun hulp. Ze leerden elkaar nog in Duitsland kennen, maar Grósz verliet dat land nog vroeger dan de Pals vanwege zijn joodse komaf. Met behulp van zijn verwanten kon hij in Praag met zijn firma beginnen en vandaar nodigde hij Pal uit om in het AB Barrandov atelier te werken. Pal accepteerde zijn uitnodiging en begon zijn werkzaamheden in Praag in de zomer van 1933.

Na Praag vertrok Pal met zijn vrouw op voorstel van Grósz ${ }^{42}$ naar Parijs waar ze in een kamer van Hotel Vaugirard woonden en werkten. ${ }^{43}$ Pal kreeg daar al opdrachten van Philips. Toen hij een film wilde maken waarin alles uit glas bestond, vroeg Sies Numann, de publiciteitschef ${ }^{44}$ van Philips, hen om naar Nederland te verhuizen. ${ }^{45}$ 


\section{$4 \quad$ Nederland}

Pal verhuisde naar Nederland, ${ }^{46}$ naar Eindhoven omdat hij daar zijn poppenfilm Het Aetherschip (1934) kon vervaardigen. ${ }^{47}$ Daardoor ontstond de Pal Studio, "de meest professionele animatiestudio van Nederland" in deze periode, ${ }^{48}$ waarmee er een aanzet werd gegeven tot de Nederlandse poppenfilmindustrie. ${ }^{49}$ Hij werkte enkel tussen 1934 en 1939 in Nederland, maar zijn verblijf en werk waren van groot belang. ${ }^{50}$

Hij vervaardigde daar ongeveer 25 films, ${ }^{51}$ waaronder vooral poppenfilms, maar ook enkele tekenfilms. Hij werkte niet alleen voor Philips. Hij maakte ook films voor de firma Horlicks, ${ }^{52}$ voor de PTT, ${ }^{53}$ voor Bio Vacantieoord, ${ }^{54}$ voor Verkade ${ }^{55}$ en één in opdracht van Sándor Szlatinay ${ }^{56}$ en Dezső Uray. ${ }^{57}$

Deze films waren geen gewone reclamefilms, maar boden amusement aan het publiek. De reclame kwam meestal pas aan het einde van de reclamefilm tevoorschijn. In een recensie over de film Philips Broadcast 1938 schreef een journalist dat deze film '[...] in scherp contrast met het gewone type reclame-film [stond], dat in de meeste gevallen vervelend en zoutloos is, omdat de reclame er veel te dik boven op ligt. Wij hebben veel producten van deze categorie gezien die op verstandige mensen eerder de uitwerking van een anti-reclame hadden. Pàl's [sic] reclamewerk daarentegen vormt door zijn ongedwongen artisticiteit en zijn bescheidenheid de beste aanbeveling voor de onderneming die het uitbrengt $[\ldots]$ Philips slaat met deze film doelbewust een nieuwen weg in: den weg van de "sponsored film"., 58

\subsection{Het puppetoon-systeem en kenmerken van zijn films}

Het woord 'Puppetoon' is een samenstelling van de woorden 'puppet' (pop) en 'cartoon' (tekenfilm). Pal vervaardigde zijn poppenfilms op basis van de grondregels van de tekenfilm. ${ }^{59}$ Dat betekent dat hij eerst altijd een bijna klare tekenfilm liet maken die hij en zijn medewerkers daadwerkelijk als basis van de toekomstige poppenfilm gebruikten. ${ }^{60}$ Daarnaast wilde hij met zijn poppen dezelfde soepele bewegingen bereiken waarvoor vroeger alleen tekenfilmfiguren geschikt waren. ${ }^{61}$

Eerst werden de figuren en de bewegingen dus op papier getekend. Uit deze animatietekeningen werd dan beeld voor beeld een proeffilm (lijntest) gemaakt. ${ }^{62}$ Soms draaiden ze die proeffilm 20-100 keer om er zeker van te zijn dat de bewegingen in orde waren. ${ }^{63}$ Als alles in orde 
was, werden na de animatietekeningen constructietekeningen gemaakt en na de constructietekeningen ${ }^{64}$ driedimensionale, ongeveer $15 \mathrm{~cm}$ hoge poppen, ${ }^{65}$ vooral uit hout. De armen, benen en hals waren elektrische draden met een enkelvoudige dikke koperen kern, zo konden ze in de juiste houding gebogen worden. ${ }^{66}$ Kleren kregen de poppen alleen van verf, het werd namelijk snel duidelijk dat de stofbekleeding onhanteerbaar is vanwege de vouwen. Bovendien volgden de echte kleren de beweging van de poppen ook niet. ${ }^{67}$

Er waren twee soorten animatiepoppen: verzamelpoppen en fasepoppen. De verzamelpoppen hadden bewegende ledematen, kopjes en nekjes, of verwisselbare kopjes. ${ }^{68}$ De nieuwe onderdelen werden met behulp van pennen en gaten aan de pop bevestigd. Als de pop sprak of zong, werden er series losse koppen gebruikt waarin de mondfases al vooraf één voor één uitgesneden waren. Er waren ook poppen die uit drie stukken bestonden: uit een onderlijf met benen, een bovenlijf met armen en een kop met hoed. Zo kon men van elk van de drie gedeeltes een fasenreeks maken. Het aantal combinatiemogelijkheden was onbeperkt. ${ }^{69}$

Fasepoppen waren stuk voor stuk uitgesneden en moesten tijdens de opnames omgewisseld worden. ${ }^{70}$ Het voordeel was dat de medewerkers elke beweging, elk moment vooraf precies in konden stellen. Wanneer ze de poppen beeld voor beeld moesten verbuigen, ging de vorige positie van de poppen altijd verloren en zo konden ze fouten niet meteen corrigeren. ${ }^{71}$

Maar de uitvinding van Bax, een speciaal uitrichtapparaat, namelijk een plank waarop poppen achter elkaar gezet konden worden, maakte later mogelijk dat ook de verzamelpoppen van tevoren in de juiste posities gebogen konden worden, zodat men bewegingsfouten kon vermijden. ${ }^{72}$ Daardoor werd het proces efficiënter omdat men op deze manier geen poppen meer moest vervaardigen voor letterlijk elke bewegingsfase. ${ }^{73}$

Aan het begin waren de bewegingen en gezichtsuitdrukkingen van de poppen nog niet zo levendig en expressief als later. ${ }^{74}$ In zijn eerste film voor Philips, Het Aetherschip (1934) probeerde Pal de dynamiek bijvoorbeeld nog door snelle montages te bereiken, ${ }^{75}$ maar de ontwikkeling tijdens de periode 1934-1939 is goed waarneembaar. Toch was die eerste al een groot succes. 


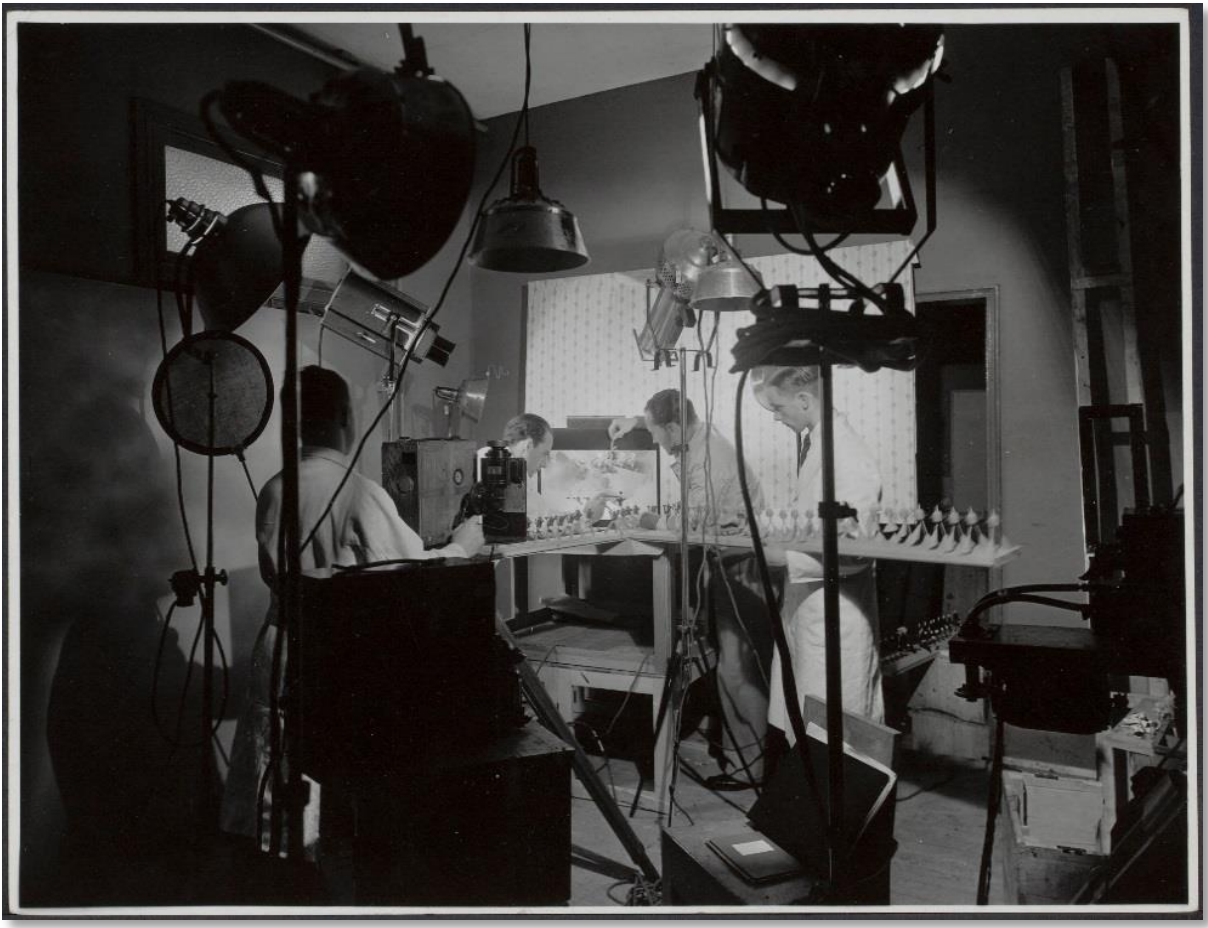

Illustratie 2: Aethersymphonie (Bron: collectie Stichting EYE Film Instituut Nederland)

Amerikaanse tekenfilms (bv. Felix the $\mathrm{Cat}^{76}$ ) waren voor Pal een voorbeeld, zoals te zien is aan de bewegingsstijl van zijn poppen. Met die poppen probeerde Pal zoals gezegd dezelfde bewegingen te bereiken die in een tekenfilm mogelijk waren. Ze liepen, zongen en dansten zoals tekenfilmfiguren, ze werden langer en korter op het ritme van de muziek. ${ }^{77}$

Dit effect, dat de basis van zijn puppetoon-systeem was dus en waarmee hij een radicale verandering in het vervaardigen van poppenfilms bracht, bereikte hij ten eerste door het vervaardigen van meerdere poppen van dezelfde figuur met verwisselbare ledematen. Daarnaast bogen ze de poppen van tevoren in de gewenste houdingen. Zo begon het animeren bij Pal al voor de opnames en deze combinatie van buigen en wisselen van ledematen gaf eindelijk dat beetje extra waardoor het effect van vloeiende bewegingen en expressieve gezichtsuitdrukkingen mogelijk werd. Door het gebruiken van één enkele pop was het bereiken van zo'n hoge expressiviteit en dynamiek niet mogelijk. ${ }^{78}$ 
Daarnaast kregen de beelden van zijn films door het gebruik van de poppen meer diepte. Aan de ene kant verhoogde dit het abstracte effect. Aan de andere kant waren zijn films dankzij de driedimensionale objecten, zoals Frans Dupont zei in zijn causerie op de VARA, 'een kleurenwonder'. ${ }^{79}$ Dupont vond dat de gewone tekenfilms vanwege hun platte vlak dezelfde kleureffecten als Pals poppenfilms niet konden weergeven. Deze fijne kleurvariaties waren onder andere te danken aan het gebruik van schaduweffecten op de poppen en in het decor. ${ }^{80}$ Een andere oorzaak van die kleureneffecten was dat Pal voor zijn films het zogenaamde Gasparcolor-systeem gebruikte dat door de Hongaar Béla Gáspár uitgevonden werd. Daardoor kon men, in tegenstelling tot andere procédés, ${ }^{81}$ echt het effect van felle kleuren bereiken. ${ }^{82}$ Hoe belangrijk dit systeem in die periode was, bewijst het feit dat het naast Pal ook door de toen bekendste avant-garde filmmakers van Europa gebruikt werd. ${ }^{83}$

Een ander kenmerk van de films van Pal is verder dat ze avantgardistische elementen bevatten. Een voorbeeld daarvan is de film The Philips Broadcast 1938 en de scène I saw the Harbourlights waarin een paar op een spiegelende vloer danst. Er verschijnen opeens danseressen naast hen die een choreografie met abstracte figuren opvoeren. Een ander voorbeeld is de scène uit The ballet of Red Radiovalves (1938) waarin de op het ritme van de muziek bewegende rode radiobuizen een abstract beeld geven.

Dat hij tijdsbeelden verborg in zijn films is ook typerend voor hem. In De Reddingsbrigade (1937) werd bijvoorbeeld een typisch tafereel uit de jaren 30 uitgebeeld waarin een slager en een kruidenier klagen dat het moeilijke tijden waren. In een andere scène verbeelden robots marcherende legers. ${ }^{84}$ Zijn mening over politiek door films uiten was trouwens ook niet ongewoon voor hem. ${ }^{85}$

Hij liet in zijn films niet alleen typische tijdsbeelden zien, maar om de figuren van de multiculturele massascènes (die overigens ook kenmerkend voor zijn werk zijn) of de plaats van de handeling makkelijker herkenbaar te maken, maakte Pal ook vaak gebruik van stereotypen. In de film De Tooveratlas (1935) zien we bijvoorbeeld een 'csárda', een soort Hongaarse kroeg die vroeger langs de belangrijkste Hongaarse wegen stond, ${ }^{86}$ met rode geraniums, een sjadoef, een violist met een walrussensnor, etc. Allemaal stereotiepe beelden van Hongarije dus die duidelijk maken waar de handeling zich afspeelt. (Daarnaast bewijst dit voorbeeld ook dat Pal vanwege zijn afkomst regelmatig een klein Hongaars stukje in zijn films probeerde te verbergen.) 
Terwijl Pal nooit de bedoeling had om met die techniek iemand te beledigen, werd hij vanwege zijn Jasper-films die hij in de VS vervaardigde, van racisme verdacht. In de film Jasper and the watermelons zien we ten eerste de hoofdpersonage, Jasper, een klein Afro-Amerikaans jongetje dat uitpuilende ogen en vlezige lippen heeft, en zijn moeder met overgewicht, wat samen het beeld van slavernij opriep bij de Amerikanen. Daarnaast liet hun omgeving de toeschouwers aan de stereotypen denken dat AfroAmerikanen arm zijn, honger lijden, dat hun kinderen stelen, watermeloen eten en bang zijn voor alles. De techniek die in Europa werkte, ging in een andere cultuur, in een andere politieke situatie de verkeerde kant op. Toch kon Pal met die films uiteindelijk verandering brengen in de beoordeling van de stereotiepe beelden van Afro-Amerikanen: ze veranderden dankzij hem vanuit een negatieve stereotype in culturele sjabloons. ${ }^{87}$

\subsection{De invloed van Pal op de Nederlandse animatie}

Zijn Pal Studio, die snel 'één van de grootste gespecialiseerde filmstudio's' van Europa werd, ${ }^{88}$ gaf een impuls aan de animatiefilmindustrie in Nederland. ${ }^{89}$

Daarnaast gaf Pal zijn kennis aan zijn medewerkers door. ${ }^{90}$ Sommigen van hen wisten helemaal niets over het vervaardigen van een film voordat ze in contact kwamen met Pal. ${ }^{91}$ In de jaren 30 was er namelijk nog geen filmopleiding in Nederland. Mensen maakten zich het vak meestal eigen in het reclamevak als illustrator of grafisch ontwerper, of in de praktijk bij verschillende filmmaatschappijen. ${ }^{92}$

Maar de kennis en erfenis van Pal was ook voor de Duitsers van belang. Joseph Goebbels, de leider van het Reichsministerium für Volksaufklärung und Propaganda vond dat de filmindustrie de uitkomst van de oorlog zou kunnen beïnvloeden. Daarom werden er maatregelen genomen die de filmindustrie en de daarin werkenden steunden, en hoefden, nadat Nederland bezet werd door de Duitsers, onder anderen ook Nederlandse filmmakers geen dienst te doen aan het front of in fabrieken. Daarnaast werden er in de door Duitsers bezette landen een aantal nieuwe animatiestudio's opgericht.

De nazi's vonden namelijk dat de animatiefilm deel van de hoog geprezen Kulturfilm uitmaakte en Goebbels had er ook grote plannen mee. Op basis daarvan is het niet verrassend dat de Duitsers juist het opgeleide personeel van de Pal Studio belangrijk voor hun doelen vonden. Ze wil- 
den dat ze in hun filmbedrijven gingen werken, bijvoorbeeld bij Nederland Film. ${ }^{93}$ Frans Hendrix, een oud-Palmedewerker noemde het 'toegepaste Arbeitseinsatz'. ${ }^{94}$

De oprichter van Nederland Film was Egbert van Putten, een Nederlandse nationaalsocialist. Met de oprichting van deze filmmaatschappij probeerden de nazi's in 1941 terrein te winnen in de Nederlandse filmindustrie.

Nederland Film vond dat ze op het terrein van de animatiefilm als 'de opvolger van de Pal Studio' beschouwd kon worden. Het verschil was dat ze geen poppenfilms maar alleen tekenfilms wilden maken. Een aantal oud-Palmedewerkers moest bij Nederland Film in dienst treden en ze namen ook de technische uitrusting van de studio over, zoals de camera die voor beeld-voor-beeldopnames geschikt was. ${ }^{95}$

Vanaf het begin van 1943 werden de mensen die bij Nederland Film werkten over twee Arbeitsgruppen verdeeld voor de Haagse filialen van de Duitse filmmaatschappijen Bavaria Filmkunst en Fischerkoesen Film Produktion. Deze studio's noemden zichzelf Arbeidsgruppe Holland en hadden allebei een door Pal opgeleid hoofd. Een Haarlemse tekenaar H.G. Kannegieter gaf leiding aan het filiaal Bavaria Filmkunst Arbeitsgruppe Holland, maar na korte tijd nam oud-Palmedewerker A.C.J. Holla zijn positie over. ${ }^{96}$ Het personeel van de Fischerkösen studio werd geleid door Hill Beekman. ${ }^{97}$

De erfenis van Pal had daarnaast ook invloed op het werk van Nederlandse filmmakers tijdens en na de Tweede Wereldoorlog, bv. op 'Machilsto'. 'Machilsto' is samengesteld uit de beginletters van de volgende namen: Piet Maas, Joop Schillemans en Joop Stolk. Deze mensen probeerden in plaats van reclameopdrachten onafhankelijke films te vervaardigen en ze konden na wat moeilijkheden de films Jaantjes Droom, Van Elfen en Kabouters (1946) en Woning-problemen (1947) maken. Ze gebruikten de films van Pal als model, de invloed van Pals werk is te zien aan hun poppen en aan het decor van die films. ${ }^{98}$

Het boek Poppen voor de lens begint het verhaal van de animatiefilm na het tijdperk van Pal met de volgende zin: 'Gelukkig had de pionier, de meester, epigonen, ${ }^{99}$ waaronder Joop Geesink en Maarten Toonder. ${ }^{100}$

Hun firma was de Geesink-Toonder Tekenfilmproductie. ${ }^{101}$ Ze namen een aantal oud-Palmedewerkers in dienst, bijvoorbeeld Jan Coolen en Frans Hendrix. ${ }^{102}$ Geesink en Toonder kregen opdrachten van onder anderen Philips nadat ze een proeffilm naar Eindhoven hadden meegebracht. Sies Numann gaf hun na het zien van de film het nodige budget om de 
productie te voltooien, waarschijnlijk vanwege het vooroorlogse succes van de Pal-reclamefilms. ${ }^{103}$

Ze maakten tijdens de oorlog vijf reclamefilmpjes voor Philips, maar die werden nooit vertoond. Toch was Philips ook na de bezetting een belangrijke opdrachtgever van hen, ${ }^{104}$ terwijl ze vanaf 1943 niet meer samenwerkten. Vanaf dat jaar bestonden er twee studio's, één waar tekenfilms en één waar poppenfilms geproduceerd werden.

De nieuwe studio van Joop Geesink heette Joop Geesink's Filmproductie en die studio richtte zich op het vervaardigen van poppen- en reclamefilms. ${ }^{105}$ Later werd het Dollywood ${ }^{106}$ genoemd $^{107}$ en werd het één van de grootste Nederlandse filmbedrijven die een belangrijke rol speelde in de geschiedenis van de Nederlandse animatiefilm. ${ }^{108} \mathrm{Na}$ de oorlog toen Geesink weer actief mocht zijn binnen het filmwezen (hij mocht van de filmzuiveringscommissie zes maanden lang niet werken omdat hij films voor de Duitsers had vervaardigd), ${ }^{109}$ zocht hij met Sies Numann naast zijn oude mederwerkers nieuwe en ook specifiek oud-Palmedewerkers. Koos Schaadee, Theo Doreleyers, Wim Gomes en Joszef Misik begonnen bij hem te werken. ${ }^{110}$

Welke invloed had Pal nog op Dollywood behalve de door hem opgeleidde medewerkers? Het boek George Pal in Holland stelt: 'De films die Geesink maakte, waren qua opzet dezelfde als die van Pal. Ook hier reclamefilms, die een show van muziek en dans vertonen, of films, waarin het tot een goed einde komt dankzij het product. ${ }^{111}$ Aan het begin leken ook Geesinks poppen erg op de poppen van Pal, maar later werden ze minder gestileerd en ze werden steeds meer beweegbaar en steeds meer geschikt om gevoelens uit te drukken. Geesink ontwikkelde dus ondertussen zijn eigen stijl en hij vond ook nieuwe technieken uit, ${ }^{112}$ maar de Pal Studio kan echt 'als de belangrijkste voorloper van Dollywood worden beschouwd. 113

Geesink werd zo succesvol in het maken van animatiefilms dat Pal in de jaren 50 de Puppetoondelen van zijn nieuwe film Tom Thumb (1958) door Geesinks Dollywood wilde laten vervaardigen. De twee pioniers van de Nederlandse animatie kwamen dus ook persoonlijk in contact met elkaar. Het werk van Geesink was te duur geweest en Pal had geen groot budget, daarom sloten ze uiteindelijk geen contract. ${ }^{114}$ Maar Pals zoon Dave die ook animator werd, heeft later in 1966 in Dollywood meegewerkt aan Philips Cavalcade 75 Years of Music (1967). ${ }^{115}$ 


\section{De Verenigde Staten}

Pals films werden niet alleen in Nederland, maar ook in andere landen gedraaid en ze wekten niet alleen internationaal, maar ook intercontinentaal interesse. ${ }^{116}$ Nadat zijn film De Philips Broadcast 1938 in Londen werd vertoond, werd hij uitgenodigd om in de VS te onderhandelen met grote filmmaatschappijen die geïnteresseerd waren in zijn uitvinding. ${ }^{117}$ Op 21 februari 1938 vertrok hij dus met het schip Berengaria naar de VS voor een werkbezoek. ${ }^{118}$ Hij onderhandelde erover dat hij in Eindhoven poppenfilms zou gaan vervaardigen voor voorprogramma's van Amerikaanse bioscopen, maar daar is het nooit van gekomen. ${ }^{119}$

Tijdens deze reis had hij niet alleen onderhandelingen met grote filmmaatschappijen, maar hield hij op de avond van zijn aankomst (15 maart 1938) in New York ook een lezing aan de Columbia Universiteit. Tijdens de lezing werden ook verschillende films van hem gedraaid. Aan het einde van de lezing zei prof. Russel Potter dat het de meest interessante avond was van het seizoen. ${ }^{120}$

Het werk van Pal maakte eveneens indruk op onder anderen de New Yorkse filmrecensenten, zo verscheen er in The New York Times een waarderend artikel over hem met de titel Pal of The Puppet Pictures. De schrijver van dit artikel voorspelde een grote toekomst voor Pal in de $\mathrm{VS}^{121}$

Pal vroeg meerdere keren een visum naar Amerika aan omdat hij bang was voor de nazi's en de Tweede Wereldoorlog, maar hij werd altijd afgewezen omdat het Hongaarse quotum vol was. Pas vlak voor het accepteren van het Britse staatsburgerschap kreeg hij dat visum ${ }^{122}$ en vertrok hij met zijn gezin in november 1939 naar de VS. Dit was de laatste mogelijkheid om te vluchten. In de studio waren de medewerkers bezig met de tekenfilm Vriend in Nood voor Bio Vacantieoord die in maart 1940 werd afgerond. Daarna werd de Pal Studio gesloten. ${ }^{123}$

Pal en zijn gezin kwamen in New York aan, waar Pal een gastlezing gaf aan de Columbia Universiteit. Ondertussen zag Barney Balaban, het hoofd van Paramount Pictures in New York één van zijn poppenfilms en hij bood hem een baan aan. Pal accepteerde de job en koos uit de aangeboden steden voor Hollywood, dat het echte centrum van de filmproductie was. Hij opende daar een eigen studio waar hij weer poppenfilms vervaardigde met ongeveer 25 medewerkers voor Paramount Pictures. In 1945 werkte hij al met 45 mensen. ${ }^{124}$ Een paar namen uit zijn personeel waren Willis O'Brien (die later voor de speciale effecten van King Kong 
verantwoordelijk was) en Wah Chang en Gene Warren, met wie hij later bijvoorbeeld aan The Time Machine meewerkte ${ }^{125}$ en die later ook aan de productie van Star Trek deelnamen. ${ }^{126}$

Eén van belangrijkste films van deze periode is Tulips Shall Grow (1942) waarmee Pal op de bezetting van Nederland reflecteerde. Hij creëerde daarvoor de Screwball Army, een parodie op het naziregime. ${ }^{127}$ Hij zei: 'I was mad for what they did to that country. I hate any kind of ism, any totalitarian system, be it fascism, communism, or any other ism. ${ }^{128}$

Hij was ook geïnteresseerd in volksverhalen van Afro-Amerikanen. Hij ontwierp het figuur van Jasper, een klein Afro-Amerikaans jongetje en hij maakte een aantal films over zijn avonturen. ${ }^{129}$

Tussen 1941 en 1947 produceerde Pal in totaal meer dan 40 films voor Paramount en zes ervan werden voor de Oscars genomineerd. In 1943 kreeg hij een speciale Oscar voor de animatietechniek die hij had ontworpen.

Tijdens de Tweede Wereldoorlog maakten ze in de studio ook trainingfilms voor het leger van de Verenigde Staten, waarin ze verschillende tactieken verbeeldden met kleine schepen en landschappen. ${ }^{130}$ 'Every cartoon studio in Hollywood was making training pictures, including Walt Disney. I remember we made a training film of the D-day invasion of Normandy a year before it actually happened. The whole set was closed, and there were guards on duty to keep people out. It was all very secret. ${ }^{131}$

Vanaf 1947 was Paramount niet meer geïnteresseerd in de Puppetoons. Dat was geen probleem voor Pal, hij wilde al met speelfilms experimenteren. Nadat hij zijn laatste poppenfilm Romeow and Julicat (1947) beëindigde, begon hij zijn nieuwe ideeën te realiseren ${ }^{132}$ waarmee hij wereldberoemd werd. ${ }^{133}$ Ik noem hier zijn belangrijkste films.

Eén van de belangrijkste films uit de VS was Destination moon (1950). Deze film kreeg de Oscar voor de beste speciale effecten en Pal werd na deze film beschouwd als de man die een nieuwe golf van sciencefiction liet beginnen: de golf van sciencefictionfilms die op een intelligente manier vervaardigd werden. Destination moon werd het prototype van een moderne sciencefictionfilm. ${ }^{134}$

Als volgende besloot hij het klassieke boek When Worlds Collide van Philip Wylie en Edwin Balmer te verfilmen. Ondanks de problemen met Paramount ${ }^{135}$ werd deze film ook een succes: het won ook een Oscar voor de beste speciale effecten. ${ }^{136}$ 
Toen Pal op zoek was naar volgende projecten, vond hij The War of the Worlds $(1953)^{137}$ waarmee hij weer een Oscar won. Deze film is één van de beste scienefictionthillers ooit ${ }^{138}$ en het werd het sjabloon van alle latere films die over buitenaardse invasie gaan, onder andere van Independence Day van Steven Spielberg (1996) of van het superheldenepos The Avengers (2012). ${ }^{139}$

De erfgenamen van H.G. Wells boden Pal na het succes van The War of the Worlds (1953) de mogelijkheid aan om elk verhaal van Wells te verfilmen dat hij maar wilde. Pal las de verhalen door en koos The Time Machine. MGM accepteerde het project. ${ }^{140}$ Deze film leverde het meeste geld op voor Pal en was in dat jaar ook voor MGM een groot financieel succes. Er was een breed publiek geïnteresseerd in sciencefictionfilms en met deze film kreeg Pal ook de bewondering van een nieuwe generatie filmfans. The Time Machine (1959) kreeg ook een Oscar voor zijn speciale effecten. ${ }^{141}$

Pal stierf in 1980 in Beverly Hills, terwijl hij nog aan zes films werkte. ${ }^{142} \mathrm{Na}$ zijn dood werd er een serie lezingen gehouden over zijn pionierswerk. Zijn oud-medewerkers maakten een herdenkingsfilm over hem met de titel The Fantasy Film Worlds Of George Pal. ${ }^{143}$

$\mathrm{Nu}, 110$ jaar na zijn geboorte is het hoogste tijd om het belang van zijn werk weer bekend te maken. Niet alleen zijn geboortestad Cegléd en zijn geboorteland Hongarije kunnen trots zijn op hem en op al die ongelooflijke resultaten die hij bereikte, maar zijn werkzaamheden zijn ook voor Nederland en voor het onderzoek van de Hongaars-Nederlandse betrekkingen van groot belang.

Pal met zijn Pal Studio was bepalend en onvervangbaar bij het begin en de verdere ontwikkeling van de Nederlandse animatie. Dat is geen verwaarloosbaar resultaat aangezien hij slechts vijf jaar lang in Nederland woonde en pas 31 was toen hij dat land verliet. De vragen hoe precies, onder welke omstandigheden, met wie hij in Nederland werkte, of zijn Hongaarse afkomst ook bepalend was voor zijn werk daar, vereisen nog verder onderzoek en zullen waarschijnlijk nog interessante resultaten opleveren. 
Noten

1 Dizseri, És mégis mozog....: az animáció magyar mesterei: a kezdetek.

2 Pesti Megyei Levéltár, XXXIII.1., ceglédi polgári születési anyakönyv 1907-1909, 129. bejegyzés

3 Hickman, The films of George Pal, 17.

4 'Anyakönyvi értesítés', 4.

5 Dizseri, És mégis mozog ...: az animáció magyar mesterei: a kezdetek, 44.

6 Pesti Megyei Levéltár, XXXIII.1., ceglédi polgári születési anyakönyv 1907-1909, 129. bejegyzés

7 Szabó, Arcok, képek Ceglédröl, 109.

8 (https://www.youtube.com/watch?v=WlRyE4U-dDM). (geraadpleegd op 01.12.2017)

9 Schepp\&Kamphuis, George Pal in Holland 1934-1939, 9.

10 Moholy-Nagy Müveszeti Egyetem, Levéltár, Anyakönyvek, Lt. 6/a 29. kötet, 42. szám és Lt. 6/b 23. kötet, 193. szám.

11 Dizseri, És mégis mozog...: az animáció magyar mesterei: a kezdetek, 44.

12 Moholy-Nagy Müveszeti Egyetem, Leváltár, Anyakönyvek, Lt. 6/a 29. kötet, 42. szám és Lt. 6/b 23. kötet, 193. szám.

13 Dizseri, És mégis mozog...: az animáció magyar mesterei: a kezdetek, 44.

14 Hickman, The films of George Pal, 17-18.

15 Dizseri, És mégis mozog...: az animáció magyar mesterei: a kezdetek, 44-45.

16 Hickman, The films of George Pal, 18.

17 (https://www.youtube.com/watch?v=WIRyE4U-dDM). (geraadpleegd op 01.12.2017)

18 Hickman, The films of George Pal, 18.

19 'Ik denk dat het werken met hout mij later ongeloofelijk veel hielp bij de Puppetoons. Ik denk dat ik zonder deze ervaringen het Puppetoonsysteem nooit zou hebben kunnen uitvinden.' (vertaald door Maja Szücs) Ibidem, 18.

$20 \mathrm{Er}$ waren 250.000 werklozen in die tijd in Hongarije. (http://www.rubicon.hu/magyar/nyomtathato_verzio/a_szocialdemokrata_munkasno politika_a_20_szazad_elso_feleben/). (geraadpleegd op 01.12.2017)

21 Dizseri, És mégis mozog...: az animáció magyar mesterei: a kezdetek, 45.

22 Hickman, The films of George Pal, 18.

23 János Halász is in Hongarije geboren in 1912 en hij is in London, Engeland gestorven in 1995. Aan het begin van zijn carrière werkte hij, nog in Hongarije, samen met George Pal. In 1936 verhuisde hij naar Engeland waar hij onder de naam John Halas bekend werd. In 1940 richtte hij daar samen met zijn vrouw Joy Batchelor de animatiestudio Halas-Batchelor Cartoon Films op. Dat de Britse animatie een internationale reputatie bereikte, was te danken aan het werk van die studio. Hun meest ambitieuze werk was de verfilming van Animal Farm van George Orwell. Het was de eerste Britse avondvullende animatiefilm. Shail, British film directors a critical guide, 88-90.

24 Imre Hajdú is in Hongarije geboren in 1910 en in Frankrijk gestorven in 1989. Aan het begin van zijn carrière als animator werkte hij samen met George Pal. Maar vanwege de beperkte werkgelegenheid in Boedapest verhuisde hij naar Berlijn. Ten gevolge van de politieke veranderingen in de jaren 30 in Duitsland ging hij verder 
naar Parijs waar hij van naam veranderde. Zo werd hij Jean Image. In 1946 vervaardigde hij zijn eerste zelfstandige film Rhapsodie de Saturne (De rapsodie van Saturnus), waarmee hij meteen de eerste prijs voor de beste animatiefilm won op het Filmfestival van Cannes. Daardoor werd hij een bekende en geliefde Franse artist en hij richtte daarmee het genre van de Franse nationale animatie op. Door zijn latere werkzaamheden kon de Franse animatie deel uitmaken van de internationale animatieproductie. (http://www.szineszkonyvtar.hu/contents/f-j/jeanielet.htm). (geraadpleegd op 01.02.2017)

25 Schepp\&Kamphuis, George Pal in Holland 1934-1939, 10.

26 Felix the Cat is een tekenfilmfiguur, bedacht door de Amerikaanse animator Otto Messmer. Hij was de populairste tekenfilmfiguur ter wereld in de jaren 20, voor het verschijnen van Mickey Mouse. De eerste animatieflims over Felix verschenen in 1919-1920. (https://www.britannica.com/biography/Otto-Messmer\#ref739012). (geraadpleegd op 01.12.2017) (http://catalogus.eyefilm.nl/). (geraadpleegd op 01.12.2017)

27 Oswald the Rabbit was een tekenfiguur van Walt Disney en Ub Iwerks. Er verschenen animatiefilms over hem tussen 1927-1930 in de VS. (https://www.britannica.com/biography/Walt-Disney\#ref215588). (geraadpleegd op 01.12.2017) (http://catalogus.eyefilm.nl/). (geraadpleegd op 01.12.2017)

28 Hickman, The films of George Pal, 18.

29 Schepp\&Kamphuis, George Pal in Holland 1934-1939, 10.

30 (https://www.youtube.com/watch?v=WIRyE4U-dDM). (geraadpleegd op 01.12.2017)

31 Schepp\&Kamphuis, George Pal in Holland 1934-1939, 10.

32 Costello, 'The UFA Story: A History of Germany's Greatest Film Company, 19181945', 122.

33 Ibidem. Clemens, 'The UFA Story: A History of Germany's greatest Film Company, 1918-1945', 170-171.

34 Mickey Mouse is het wereldberoemde tekenfilmfiguur van Walt Disney, bedacht in 1928. (https://www.britannica.com/topic/Mickey-Mouse). (geraadpleegd op 01.12.2017)

35 (http://www.szineszkonyvtar.hu/contents/p-z/palgyelet.htm). (geraadpleegd op 01.12.2017)

36 'Így készül a hangos trükkfilm...', 42-43.

37 Het sigarettenbedrijf dat onder de merknaam 'Haus Neuerburg' bekend werd, werd in 1908 opgericht door Heinrich en August Neuerburg in Trier. Ze waren afkomstig uit een een fabrikantenfamilie die in sigaren handelde. Tijdens de Eerste Wereldoorlog maakten ze grote winst door de stijgende consumptie van tabak en ze konden daardoor nieuwe filialen vestigen in heel Duitsland. (https://www.volksfreund.de/region/trier/die-tabak-dynastie-neuerburg-wittlicherzigarrenfabrikanten-gruenden-unternehmen-in-trier_aid-6597961). (geraadpleegd op 01.12.2017)

38 Schepp\&Kamphuis, George Pal in Holland 1934-1939, 10. Hickman, The films of George Pal, 18-19. 
39 'Dus we monteerden kleine mondjes op de poppen - geen gezicht nog, alleen monden. En daarna monteerden we er gezichtjes op en we monteerden hoedjes en armpjes en beentjes op hen. Ik maakte metaaldraadbenen met knopjes als voetjes en ik stelde series van benen samen op deze manier. En dat was de geboorte van Puppetoons.' (vertaald door Maja Szücs) Ibidem, 19.

40 Ibidem, 19.

41 Dizseri, És mégis mozog...: az animáció magyar mesterei: a kezdetek, 45.

42 Orosz, Vissza a szülöföldre!, 18.

43 Schepp\&Kamphuis, George Pal in Holland 1934-1939, 10.

44 Ibidem, 9.

45 Hickman, The films of George Pal, 19.

46 Hij werd met zijn vrouw op 30 juli 1934 geregistreerd in het Eindhovense Bevolkingsregister. Regionaal Historisch Centrum Eindhoven, BR-Eindhoven-10491-7244 Index Bevolkingsregister Eindhoven 1921-1938, folio: 21488

47 Schepp\&Kamphuis, George Pal in Holland 1934-1939, 9.

48 Peters, 'Het animatie maakproces in het archief', 105.

49 Dibbets\&Maden, Geschiedenis van de Nederlandse film en bioscoop tot 1940, 216.

50 Peters\&Barten, Meestal in't verborgene, 17.

51 Peters, 'Het animatie maakproces in het archief', 105.

52 De firma Horlicks werd in 1873 gesticht in Chicago door William en James Horlick. Ze produceerden moutmelk die ze pas in 1883 konden octrooieren. De firma bestaat nog steeds. Er werden ondertussen nieuwe producten ontwikkeld, bv. moutmelk met chocoladesmaak en ze konden ook in India een fabriek openen. (http://www.horlicks.co.uk/story.html). (geraadpleegd op 01.12.2017)

53 PTT was een afkorting van het Staatsbedrijf der Posterijen, Telegrafie en Telefonie, een bedrijf van de Nederlandse staat waarin post, telefonie en telegrafie samengebracht werden en dat in 1923 opgericht werd. (https://isgeschiedenis.nl/nieuws/geschiedenis-van-telecommunicatiebedrijven-innederland). (geraadpleegd op 01.12.2017)

54 Bio Vakantieoord werd in 1927 gesticht door de Nederlandse bioscoopbranche. Het doel van de stichting was het opzetten van een vakantieoord waar arme kinderen op advies van de dokter aan zee aansterken moesten. (http://samen100worden.nl/timeline/oprichting-stichting-bio-vacantieoord/). (geraadpleegd op 01.12.2017)

55 Verkade werd in 1886 gesticht door Ericus Gerhardus Verkade. Het was een StoomBrood en Beschuitfabriek en oorspronkelijk was haar naam 'De Ruyter'. Vandaag de dag heet de firma Koninklijke Verkade NV en produceert zij chocolade en koekjes aan de Westzijde van Zaandam. (http://www.verkade.nl/over-verkade/koninklijkeverkade/). (geraadpleegd op 01.12.2017)

56 Sándor Szlatinay werd in 1899 in Lugos, in Oostenrijk-Hongarije (tegenwoordig Roemenië) geboren . Oorspronkelijk werkte hij als tandarts, maar later werd hij componist en regisseur. Hij schreef operettes. Daarna werkte hij in Oostenrijk aan het begin van de jaren 30. Tussen 1934-1944 was hij werkzaam in Hongarije, maar vanwege de antijoodse maatregelen moest hij in 1945 emigreren.De rest van zijn leven 
woonde hij in de Bondsrepubliek Duitsland. (https://www.hangosfilm.hu/filmenciklopedia/szlatinay-sandor). (geraadpleegd op 01.12.2017)

57 Dezső Uray was een Hongaarse schrijver die in 1875 geboren is. Hij schreef toneelstukken die in verschillende Hongaarse theaters gespeeld werden. (http://mek.oszk.hu/08700/08756/html/szocikk/w/31/31913.htm). (geraadpleegd op 01.12.2017) Schepp\&Kamphuis, George Pal in Holland 1934-1939, 63.

58 Peters\&Barten, Meestal in't verborgene, 18-19.

59 Schepp\&Kamphuis, George Pal in Holland 1934-1939, 11.

60 Ibidem, 23.

61 (http://metropolis.org.hu/?pid=16\&aid=538). (geraadpleegd op 01.12.2017)

62 Schepp\&Kamphuis, George Pal in Holland 1934-1939, 11-12.

63 Jordaan, 'De toovenaar thuis. Bij de scheppers van de Nederlandse truckfilm.'

64 Schepp\&Kamphuis, George Pal in Holland 1934-1939, 36.

65 Ibidem, 38.

66 Ibidem, 12.

67 Jordaan, ,De Poesjenellenkelder der Film‘.

68 Schepp\&Kamphuis, George Pal in Holland 1934-1939, 38.

69 Ibidem, 12-13.

70 Ibidem, 38.

71 Ibidem, 13

72 Ibidem, 38

73 Jordaan, 'De toovenaar thuis. Bij de scheppers van de Nederlandsche trucfilm'.

74 Schepp\&Kamphuis, George Pal in Holland 1934-1939, 13.

75 (http://metropolis.org.hu/?pid=16\&aid=538). (geraadpleegd op 01.12.2017)

76 Hickman, The films of George Pal, 18.

77 Schepp\&Kamphuis, George Pal in Holland 1934-1939, 12-13.

78 (http://metropolis.org.hu/?pid=16\&aid=538). (geraadpleegd op 01.12.2017)

79 Schepp\&Kamphuis, George Pal in Holland 1934-1939, 17.

80 Ibidem, 16-17.

81 'Plastische truckfilm in kleuren'.

82 (http://metropolis.org.hu/?pid=16\&aid=538). (geraadpleegd op 01.12.2017)

83 (http://metropolis.org.hu/?pid=16\&aid=542). (geraadpleegd op 01.12.2017)

84 Schepp\&Kamphuis, George Pal in Holland 1934-1939, 14.

85 Hickman, The films of George Pal, 26.

86 (http://mek.oszk.hu/02100/02115/html/1-1223.html). (geraadpleegd op 01.12.2017)

87 (http://metropolis.org.hu/?pid=16\&aid=538). (geraadpleegd op 01.12.2017)

88 Schepp\&Kamphuis, George Pal in Holland 1934-1939, 9.

89 Looijen, 'Geschiedenis van de Nederlandse animatiefilm', 26.

90 Peters\&Barten, Meestal in't verborgene, 18.

91 Schepp\&Kamphuis, George Pal in Holland 1934-1939, 20. Ibidem, 27.

92 Peters\&Barten, Meestal in 't verborgene, 15-17.

93 Ibidem, 21-23.

94 Ibidem, 22-23. 
Ibidem, 33-35.

96 A.C.J. Holla was een tekenaar verbonden aan Pal Studio. Tussen mei 1938 en september 1939 werkte hij daar als chef van de schilderafdeling. Tijdens de oorlog werd hij medewerker van de animatiesectie van Nederland Film. Later werd hij tot bedrijfsleider van Bavaria Filmkunst benoemd. Na de oorlog werkte hij als reclametekenaar. (http://catalogus.eyefilm.nl/). (geraadpleegd op 01.12.2017)

97 Hill Beekman werkte voor Pal als tekenaar tussen 1934-1940. Hij solliciteerde op een advertentie in een Eindhovense krant om mee te werken aan een tekenfilm. Terwijl hij niets over tekenfilms wist, kreeg hij toch de baan. Tijdens de oorlog werd hij tot begeleider van Fischerkoesen Film Produktion benoemd. Peters\&Barten, Meestal in't verborgene, 43-45. Schepp\&Kamphuis, George Pal in Holland 1934-1939, 1920.

98 Moolenbel\&Beek, Poppen voor de lens, 18-23.

99 Epigoon betekent slaafse navolger van grote voorbeelden. Vries, Nederlands Etymologisch Woordenboek, 159.

${ }^{100}$ Moolenbel\&Beek, Poppen voor de lens, 14.

${ }^{101}$ Peters\&Barten, Meestal in 't verborgene, 55.

${ }_{102}$ Moolenbel\&Beek, Poppen voor de lens, 14.

${ }^{103}$ Peters\&Barten, Meestal in't verborgene, 60.

104 Ibidem, 62.

105 Ibidem, 69.

106 Deze naam is een woordspeling uit de woorden 'doll' (pop) en 'Hollywood'. (http://www.dutch-vintage-animation.org/index.php/nl/). (geraadpleegd op 01.12.2017)

107 Peters\&Barten, Meestal in't verborgene, 81.

${ }^{108}$ Schepp\&Kamphuis, George Pal in Holland 1934-1939, 14-15.

109 Peters\&Barten, Meestal in't verborgene, 65.

${ }^{110}$ Ibidem, 81 .

${ }_{111}$ Schepp\&Kamphuis, George Pal in Holland 1934-1939, 14-15.

112 Moolenbel\&Beek, Poppen voor de lens, 15-16.

113 Schepp\&Kamphuis, George Pal in Holland 1934-1939, 15.

${ }^{114}$ Hickman, The films of George Pal, 108.

115 Schepp\&Kamphuis, George Pal in Holland 1934-1939, 15.

116 Ibidem, 14.

117 'George Pál onderhandelt met Hollywoodsche maatschappijen', 2.

118 '... naar Amerika vetrokken', 13.

119 Schepp\&Kamphuis, George Pal in Holland 1934-1939, 14.

120 'George Pal te New York', 8.

${ }^{121}$ Ibidem

${ }^{122}$ Hickman, The films of George Pal, 20-22.

${ }^{123}$ Schepp\&Kamphuis, George Pal in Holland 1934-1939, 14.

${ }^{124}$ Hickman, The films of George Pal, 22-23.

${ }^{125}$ Ibidem, 26. 
126 (http://www.szineszkonyvtar.hu/contents/p-z/palgyelet.htm). (geraadpleegd op 01.12.2017)

127 Hickman, The films of George Pal, 26.

128 'Ik was er woedend over wat zij met dat land deden. Ik haat alle soorten ismen, alle totalitaire systemen, het fascisme, communisme of wat voor een isme het dan ook is.' (vertaald door Maja Szücs) Ibidem, 26.

129 Ibidem, 27.

130 Ibidem, 28.

131 ‘Alle tekenfilmstudio's in Hollywood maakten trainingfilms, Walt Disney ook. Ik herinner me dat wij één jaar voordat het echt gebeurde een trainingfilm hebben gemaakt over de D-day invasie van Normadië. De hele productie was gesloten en er waren bewakers in dienst om mensen buiten te houden. Dat alles was geheim.' (vertaald door Maja Szücs) Ibidem, 28.

132 Ibidem, 28.

133 Schepp\&Kamphuis, George Pal in Holland 1934-1939, 14.

134 Hickman, The films of George Pal, 45-46.

135 Ibidem, 47-48.

136 Ibidem, 55.

137 Ibidem, 58.

138 Ibidem, 70.

139 Forshaw, The War of the Worlds, 35-36.

${ }^{140}$ Hickman, The films of George Pal, 113-115.

141 Ibidem, 123.

142 Schepp\&Kamphuis, George Pal in Holland 1934-1939, 15.

143 (http://www.szineszkonyvtar.hu/contents/p-z/palgyelet.htm). (geraadpleegd op 01.12.2017)

\section{Bibliografie}

Dibbets, Karel\& Made, Frank van der, 1986. Geschiedenis van de Nederlandse film en bioscoop tot 1940. Weesp: Het Wereldvenster.

Dizseri, Eszter, 2006. És mégis mozog....:az animáció magyar mesterei. A kezdetek. Budapest: Balassi.

Eagan, Daniel, 2010. America's Film Legacy. The Authoritative Guide to the Landmark Movies in the National Film Registry. New York: Continuum.

Forshaw, Barry, 2014. The War of the Worlds. Basingstoke, Hampshire/ New York: Palgrave Macmillan, on behalf of the British Film Institute. Hickman, Gail Morgan, 1977. The films of George Pal. sl: A.S.Barnes, 
Looijen, Henk, 1983. 'Geschiedenis van de Nederlandse animatiefilm.' Broos, Kees\& Halas, John (eds.) Beeld voor beeld. Nederlandse en internationale animatiefilm. Den Haag: Stichting Holland Animation.

Moolenbel, Hans\& Beek, Tom van, 1968. Poppen voor de lens. Over poppenfilm in binnen- en buitenland. Amsterdam: Nederlandse Vereniging voor het Poppenspel,

Orosz, Márton, 2011. Vissza a szülöföldre! Kecskemét: KAFF.

Peters, Mette\& Barten, Egbert, 2000. Meestal in 't verborgene. Animatiefilm in Nederland 1940-1945. Tilburg: Uitgeverij Uniepers Abcoude; Nederlands Instituut voor Animatiefilm.

Schepp, Ole\& Kamphuis, Fred, 1983. George Pal in Holland 1934-1939. Den Haag: Kleinoffsetdrukkerij Kapsenberg.

Shail, Robert, 2007. British film directors a critical guide. Edinburgh: Edinburgh University Press. https://doi.org/10.3366/edinburgh/9780748622306.001.0001

Szabó, Alfréd, 2014. Arcok, képek Ceglédröl. Cegléd: Apáti Nyomda.

Vries, Jan de, 1997. Nederlands etymologisch woordenboek. Leiden/New York/Köln: Brill.

\section{Artikelen}

'Anyakönyvi értesítés'. 1908. Czegléd, 30.6:4.

'De Poesjenellenkelder der Film.' 1939. De Groene Amsterdammer. 8 juli.

'De toovenaar thuis. Bij de scheppers van de Nederlandsche trucfilm.' 1935. De Groene Amsterdammer. 16 november, 5-6.

'Plastische truckfilm in kleuren.' 1935. 27 februari.

'George Pal naar Hollywood.' 1938. De Gooi- en Eemlander. 67.40:9.

'George Pál onderhandelt met Hollywoodsche maatschappijen.' 1937. Het vaderland Avondblad. C 69. 20 oktober, 2.

'George Pal te New York.' 1938. De Telegraaf. 46.17.103:8.

'Így készül a hangos trükkfilm.' 1932. Szinházi élet. 22.4:42-43.

'... naar Amerika vertrokken.' 1938.Utrechts Volksblad. 1.8:13.

Costello, David R. 1997. 'The UFA Story: A History of Germany's Greatest Film Company 1918-1945, Kreimer, Klaus, Trans. Robert Kimber and Rita Kimber, New York Hill and Wang, 451 pp., Publica- 
tion Date: July 1996.' History: Reviews of new books. 25.3:122. https://doi.org/10.1080/03612759.1997.9952811

Peters, Mette. 2012. 'Het animatie maakproces in het archief'. Tijdschrift voor mediageschiedenis. Themanummer animatie. 15.1:102-129. https://doi.org/10.18146/tmg.417

Verenkotte, Clemens. 1998. 'The UFA Story: A History of Germany's Greatest Film Company 1918-1945.' The Business History Review. 72.1:170-171. https://doi.org/10.2307/3116611

\section{Internetbronnen}

DUTCH-VINTAGE-ANIMATION.ORG BY ARIE DEN DRAAK 2017. Joop Geesink - Filmpionier (http://www.dutch-vintageanimation.org/index.php/nl/). (geraadpleegd op 01.12.2017)

ENCYCLOP ÆDIA BRITANNICA Mickey Mouse. Cartoon character (https://www.britannica.com/topic/Mickey-Mouse). (geraadpleegd op 01.12.2017)

ENCYCLOPÆDIA BRITANNICA Motion-picture camera (https://www.britannica.com/technology/motion-picture-camera). (geraadpleegd op 01.12.2017)

ENCYCLOPÆDIA BRITANNICA Otto Mesmer. American animator (https://www.britannica.com/biography/Otto-Messmer\#ref739012). (geraadpleegd op 01.12.2017)

ENCYCLOPÆDIA BRITANNICA 2018. Walt Disney. American film producer (https://www.britannica.com/biography/WaltDisney\#ref215588). (geraadpleegd op 01.12.2017)

EYE FILMMUSEUM AMSTERDAM (http://catalogus.eyefilm.nl/). (geraadpleegd op 01.12.2017)

EYE FILMMUSEUM AMSTERDAM 2015. Henk Kabos: art-director van Tom Poes, Tekko Taks en Loeki de Leeuw (https://www.eyefilm.nl/collectie/collectieblog/henk-kabos-artdirector-van-tom-poes-tekko-taks-en-loeki-de-leeuw). (geraadpleegd op 01.12.2017)

GSK GROUP OF COMPANIES 2017. Our story (http://www.horlicks.co.uk/story.html). (geraadpleegd op 01.12.2017) 
HANGOSFILM Szlatinay Sándor. Zeneszerző, rendező (https://www.hangosfilm.hu/filmenciklopedia/szlatinay-sandor). (geraadpleegd op 01.12.2017)

ISGESCHIEDENIS Geschiedenis van telecommunicatiebedrijven in Nederland (https://isgeschiedenis.nl/nieuws/geschiedenis-vantelecommunicatiebedrijven-in-nederland). (geraadpleegd op 01.12.2017)

MAGYAR ELEKTRONIKUS KÖNYVTÁR Magyar Néprajzi lexikon (http://mek.oszk.hu/02100/02115/html/1-1223.html). (geraadpleegd op 01.12.2017)

MAGYAR ELEKTRONIKUS KÖNYVTÁR Uray Dezső (http://mek.oszk.hu/08700/08756/html/szocikk/w/31/31913.htm). (geraadpleegd op 01.12.2017)

METROPOLIS 2016. A Kiskakas előtt. A korai magyar animációs reklámfilm transznacionális megközelítésben (http://metropolis.org.hu/?pid=16\&aid=538). （geraadpleegd op 01.12.2017)

METROPOLIS 2016. Kommersz spektákulum vagy avantgárd utópia? Elfelejtett úttörők a magyar animáció hőskorából (http://metropolis.org.hu/?pid=16\&aid=542). (geraadpleegd op 01.12.2017)

RUBICONLINE A szociáldemokrata munkásnőpolitika a 20. század első felében (http://www.rubicon.hu/magyar/nyomtathato_verzio/a_szocialdemokra ta_munkasnopolitika_a_20_szazad_elso_feleben/). (geraadpleegd op 01.12.2017)

SAMEN100WORDEN BIO VAKANTIEOORD 2018. 1927 - Voor Alle Gezindten (http://samen100worden.nl/timeline/oprichting-stichtingbio-vacantieoord/). (geraadpleegd op 01.12.2017)

SZÍNÉSZKÖNYVTÁR 2003. Jean Image/Hajdú Imre (http://www.szineszkonyvtar.hu/contents/f-j/jeanielet.htm). (geraadpleegd op 01.12.2017)

SZÍNÉSZKÖNYVTÁR $2006 . \quad$ Pál György (http://www.szineszkonyvtar.hu/contents/p-z/palgyelet.htm). (geraadpleegd op 01.12.2017)

TRIERISCHER VOLKSFREUND 2015. Die Tabak-Dynastie Neuerburg: Wittlicher Zigarrenfabrikanten gründen Unternehmen in Trier 
(https://www.volksfreund.de/region/trier/die-tabak-dynastieneuerburg-wittlicher-zigarrenfabrikanten-gruenden-unternehmen-intrier_aid-6597961). (geraadpleegd op 01.12.2017)

YOUTUBE 2013. Pal's Puppets (https://www.youtube.com/watch?v=WlRyE4U-dDM). (geraadpleegd op 01.12.2017)

VERKADE Koninklijke Verkade. Geschiedenis (http://www.verkade.nl/over-verkade/koninklijke-verkade/). (geraadpleegd op 01.12.2017)

\section{Archieven}

Moholy-Nagy Müveszeti Egyetem, Leveltar, Anyakonyvek, Lt. 6/a 29. kotet, 42. szam es Lt. 6/b 23. kotet, 193. szam.

Peste Megyei Levéltár, XXXIII.1., ceglédi polgári születési anyakönyv 1907-1909, 129. bejegyzés

Regionaal Historisch Centrum Eindhoven, BR-Eindhoven-10491-7244 Index Bevolkingsregister Eindhoven 1921-1938, folio: 21488 